Research Paper

\title{
Additively Enhanced Antiproliferative Eifect of Interieron Combined with Proanthocyanidin on Bladder Cancer Cells
}

\author{
Andrew I. Fishman, Blake Johnson, Bobby Alexander, John Won, Muhammad Choudhury, and Sensuke \\ Konno ${ }^{\bowtie}$
}

Department of Urology, New York Medical College, Valhalla, New York, USA.

$\triangle$ Corresponding author: Sensuke Konno, Ph.D., New York Medical College, Department of Urology, Munger pavilion $4^{\text {th }}$ Floor, Valhalla, NY 10595, USA. Phone: 914-594-3745; Fax: 914-594-4428 E-mail: sensuke_konno@nymc.edu.

(c) Ivyspring International Publisher. This is an open-access article distributed under the terms of the Creative Commons License (http://creativecommons.org/ licenses/by-nc-nd/3.0/). Reproduction is permitted for personal, noncommercial use, provided that the article is in whole, unmodified, and properly cited.

Received: 2012.01.17; Accepted: 2012.01.29; Published: 2012.03.01

\begin{abstract}
Although interferon (IFN) has been often used as immunotherapy for bladder cancer, its efficacy is rather unsatisfactory, demanding further improvement. Combination therapy is one of viable options, and grape seed proanthocyanidin (GSP) could be such an agent to be used with IFN because it has been shown to have anticancer activity. We thus investigated whether combination of IFN and GSP might enhance the overall antiproliferative effect on bladder cancer cells in vitro. Human bladder cancer T24 cells were employed and treated with the varying concentrations of recombinant IFN- $\alpha_{2 b}(0-100,000 \mathrm{IU} / \mathrm{ml})$, GSP $(0-100 \mu \mathrm{g} / \mathrm{ml})$, or their combinations. IFN- $\alpha_{2 b}$ alone led to a $\sim 50 \%$ growth reduction at $20,000(20 \mathrm{~K}) \mathrm{IU} / \mathrm{ml}$, which further declined to $\sim 67 \%$ at $\geq 50 \mathrm{~K} \mathrm{IU} / \mathrm{ml}$. Similarly, GSP alone induced a $\sim 35 \%$ and $\sim 100 \%$ growth reduction at 25 and $\geq 50 \mu \mathrm{g} / \mathrm{ml}$, respectively. When IFN- $\alpha_{2 b}$ and GSP were then

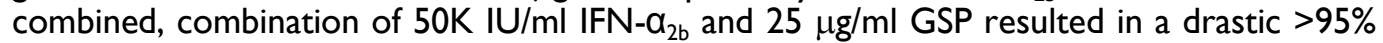
growth reduction. Cell cycle analysis indicated that such an enhanced growth inhibition was accompanied by a $G_{1}$ cell cycle arrest. This was further confirmed by Western blot analysis revealing that expressions of $\mathrm{G}_{1}$-specific cell cycle regulators (CDK2, CDK4, cyclin E and P27/Kipl) were distinctly modulated with such IFN- $\alpha_{2 b} / G S P$ treatment. Therefore, these findings support the notion that combination of IFN- $a_{2 b}$ and GSP is capable of additively enhancing antiproliferative effect on T24 cells with a $G_{1}$ cell cycle arrest, implying an adjuvant therapeutic modality for superficial bladder cancer.
\end{abstract}

Key words: interferon, proanthocyanidin, combination therapy, bladder cancer.

\section{Introduction}

Bladder cancer is the second most common urologic malignancy next to prostate cancer in the United States, and the majority of bladder cancers present as superficial $(80 \%)$ with $15 \%$ presenting as invasive cancer and $5 \%$ as metastatic disease (1). Currently, transitional cell carcinoma (TCC) is the most prevalent primary bladder tumor: 50,000 new cases are diagnosed annually and over 10,000 people die of this disease each year (2). Although endoscopic transurethral resection (TUR) is often performed as a primary therapy, $50 \%-75 \%$ of patients will yet recur in 5 years and about $10 \%$ progress to invasive disease (2).

Chemotherapy is another viable option but intravesical administration of bacillus Calmette-Guerin (BCG), an attenuated strain of Mycobacterium bovis, is currently the most effective immunotherapy for high-grade and recurrent superficial bladder cancer and carcinoma in situ (CIS) (3). In randomized studies, BCG has been shown to be superior to both mitomy- 
cin C and adriamycin (4). Intravesical BCG following TUR has also been associated with a significant improvement in progression and survival compared to TUR alone (5). In fact, this protocol has become established therapy for superficial bladder cancers, resulting in a $\sim 40 \%$ reduction in cancer recurrence (6). However, side effects of BCG therapy are common and limit its use in clinical practice, demanding a safer, more effective therapeutic modality with fewer side effects.

Interferons (IFNs) have been often used as immunotherapy for a variety of urologic malignancies including prostate, bladder, and renal cell carcinomas (7-9). Especially, IFN-a is used as an intravesical agent for treating superficial bladder cancer because it may cause only minor local and systemic toxicity (compared to BCG) (10). However, since its response rate in patients has been shown to be lower than that of BCG therapy (10), the efficacy of IFN-a combined with BCG was assessed in pilot clinical trials and animal studies $(11,12)$, indicating the better, improved outcomes. Thus, these studies would certainly encourage further exploration into other alternative combination therapies, which may lead to the safer, more effective and satisfactory results.

Proanthocyanidins are naturally occurring plant polyphenolic bioflavonoids in fruits, vegetables, nuts, seeds, flowers and bark (13). They are known as natural antioxidants, having biological, pharmacological and chemoprotective properties against oxidative stress or harmful free radicals (13-15). For example, hydrogen peroxide-induced oxidative stress was significantly reduced by proanthocyanidins in cultured macrophage and neuroactive PC-12 cells (14). They have exhibited antibacterial, antiviral, anti-inflammatory, and vasodilatory actions as well (13). Particularly, a unique grape seed proanthocyanidin (GSP) has been extensively characterized: it is a standardized water-ethanol extract from red grape seeds, consisting of oligomeric proanthocyanidins as active components (15). GSP has also demonstrated its anticancer (cytotoxic) effect on several malignancies including breast, lung and gastric cancers in vitro (16).

Accordingly, we investigated whether IFN- $a$, GSP or their combination might demonstrate the antiproliferative effect on bladder cancer cells in vitro. We also explored the underlying mechanism - how the cancer cell growth might be inhibited with such agents, focusing on the cell cycle regulation. More detailed studies are described and discussed herein.

\section{Materials and Methods Cell culture}

The human bladder cancer T24 cells, derived from a patient with TCC, were obtained from the American Type Culture Collection (Manassas, VA). Cells were cultured in McCoy's 5a medium containing $10 \%$ fetal bovine serum, penicillin $(100 \mathrm{U} / \mathrm{ml})$, and streptomycin $(100 \mu \mathrm{g} / \mathrm{ml})$, and were maintained at 37 ${ }^{\circ} \mathrm{C}$ in a humidified incubator in an atmosphere of $95 \%$ air and $5 \% \mathrm{CO}_{2}$. For experiments, cells were seeded in 6-well plates $(2 \mathrm{ml}$ per well) or T-75 flasks $(10 \mathrm{ml}$ per flask) at the initial cell density of $2 \times 10^{5}$ cells $/ \mathrm{ml}$ and were cultured with recombinant interferon- $\alpha_{2 b}$ (IFN-a $a_{2 b}$; Schering Corp., Kenilworth, NJ), grape seed proanthocyanidin (GSP; Dry Creek Nutrition, Inc., Modesto, CA) or their combinations. Cell number/viability was then assessed at specified times using the trypan blue exclusion method.

\section{Cell cycle analysis}

A FACScan flow cytometer (Becton-Dickinson, San Jose, CA), equipped with a double discrimination module, was employed for cell cycle analysis. Control or agents-treated cells $\left(\sim 1 \times 10^{6}\right.$ cells per condition) were first resuspended in $500 \mu \mathrm{l}$ of propidium iodide solution $(20 \mu \mathrm{g} / \mathrm{ml}$ propidium iodide, $0.2 \mathrm{mg} / \mathrm{ml}$ RNase, $0.2 \mathrm{mg} / \mathrm{ml}$ EDTA, $0.5 \%$ Nonidet P-40) and incubated for $1 \mathrm{~h}$ at room temperature in the dark. Following incubation, $\sim 10,000$ nuclei from each sample were analyzed on a flow cytometer, and CellFit software was used to quantify cell cycle compartments to estimate the $\%$ of cells distributed in the different cell cycle phases.

\section{Western blot analysis}

The procedure essentially followed the protocol described previously (17). Briefly, an equal amount of proteins $(7 \mu \mathrm{g})$ from control and agent-treated cell lysates was resolved by 10\% SDS-polyacrylamide gel electrophoresis and transferred to a nitrocellulose membrane. The blot was first incubated for $90 \mathrm{~min}$ with the primary antibodies against CDK2, CDK4, cyclin $\mathrm{D}_{1}$, cyclin E, or p27/Kip1 (Santa Cruz Biotechnology, Santa Cruz, CA), followed by incubation with the secondary antibody conjugated with peroxidase for $30 \mathrm{~min}$. The immunoreactive protein bands were detected by chemiluminescence following the manufacturer's protocol (Kirkegaard and Perry Laboratories, Gaithersburg, MD) and quantified using a scan densitometer (Silk Scientific, Oregon, UT).

\section{Statistical analysis}

All data were presented as the mean \pm SD (standard deviation), and statistical differences between groups were assessed with either the unpaired Student's $t$ test or one-way analysis of variance (ANOVA). Values of $p<0.05$ were considered to indi- 
cate statistical significance.

\section{Results}

\section{Effects of interferon- $\alpha_{2 b}$ and proanthocyanidin on T24 cell growth}

To examine possible effects of interferon- $a_{2 b}$ $\left(I F N-a_{2 b}\right)$ and grape seed proanthocyanidin (GSP) on T24 cell growth, cells were cultured with the varying concentrations of IFN- $a_{2 b}(0-100,000=100 \mathrm{~K} \mathrm{IU} / \mathrm{ml})$ or GSP $(0-100 \mu \mathrm{g} / \mathrm{ml})$ for $72 \mathrm{~h}$. IFN- $\alpha_{2 b}$ caused a significant $(\sim 50 \%)$ growth reduction at $20 \mathrm{~K} \mathrm{IU} / \mathrm{ml}$, which further declined to $>67 \%$ at $\geq 50 \mathrm{~K} \mathrm{IU} / \mathrm{ml}$ (Fig. 1A). Similarly, a $\sim 35 \%$ and $>90 \%$ growth inhibition were attained with 25 and $\geq 50 \mu \mathrm{g} / \mathrm{ml}$ of GSP, respectively (Fig. 1B). A drastic growth reduction ( $90 \%)$ with 50 $\mu \mathrm{g} / \mathrm{ml}$ GSP was actually due to a cytotoxic effect, evidenced by $\sim 30 \%$ of cells having been dead. These results thus show that IFN- $\mathrm{a}_{2 b}$ and GSP are capable of inhibiting T24 cell growth but GSP can also induce cytotoxic cell death at the higher $(\geq 50 \mu \mathrm{g} / \mathrm{ml})$ concentrations.
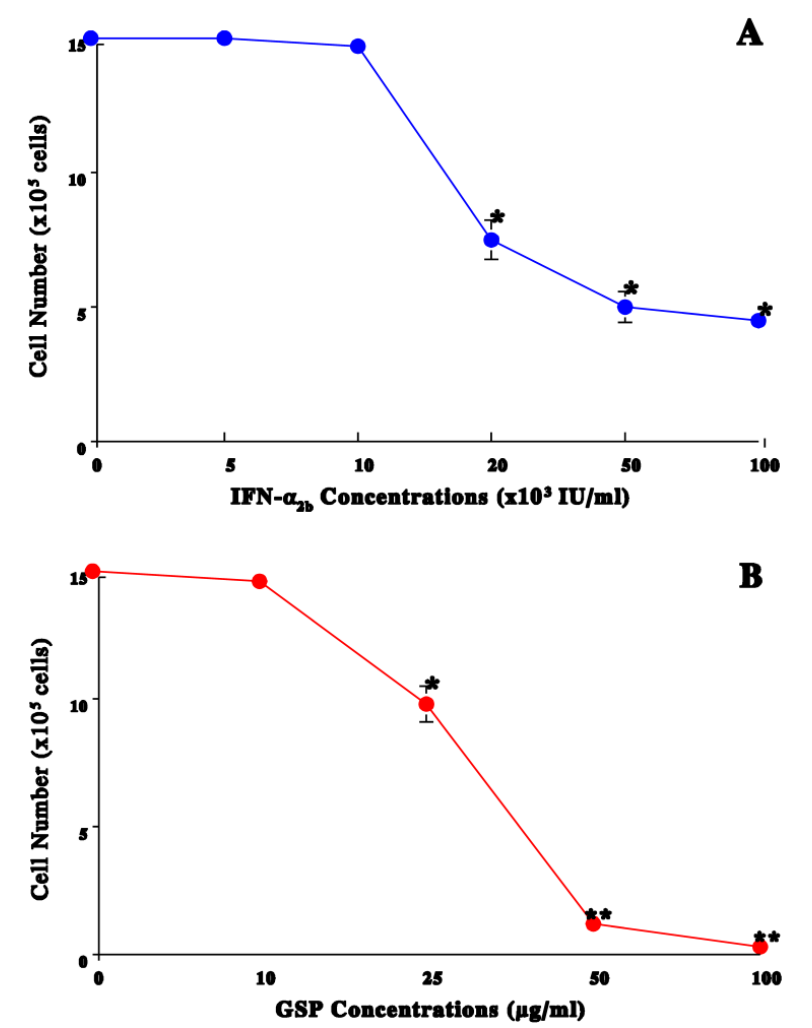

Fig. I. Effects of IFN- $\alpha_{2 b}$ or GSP on T24 cell growth. Cells were cultured with the varying concentrations of either IFN- $\alpha_{2 b}$ $(0-100,000 \mathrm{IU} / \mathrm{ml})$ or GSP $(0-100 \mu \mathrm{g} / \mathrm{ml})$, and cell numbers in IFN- $\alpha_{2 b}$-treated $(\mathbf{A})$ or GSP-treated $(\mathbf{B})$ cells were determined at 72 h. All data represent mean \pm SD (standard deviation) from three independent experiments $\left(* p<0.05 ; *^{*} p<0.01\right)$.

\section{Additive antiproliferative effects of IFN- $\alpha_{2 b}$ and GSP}

It was tempting to examine whether combinations of IFN- $a_{2 b}$ and GSP might improve the antiproliferative effects. As $25 \mu \mathrm{g} / \mathrm{ml}$ of GSP appeared to induce a moderate ( $35 \%)$ growth inhibition (Fig. 1B), this concentration was used in combination with the varying concentrations of IFN- $\mathrm{a}_{2 b}$. Such studies showed that combinations of GSP $(25 \mu \mathrm{g} / \mathrm{ml})$ and IFN- $\mathrm{a}_{2 \mathrm{~b}}$ at $10 \mathrm{~K} \mathrm{IU} / \mathrm{ml}$ (little effect by itself), $20 \mathrm{~K} \mathrm{IU} / \mathrm{ml}$ (a $\sim 50 \%$ inhibitory effect), and $50 \mathrm{~K} \mathrm{IU} / \mathrm{ml} \mathrm{(a} \sim 67 \%$ inhibitory effect) led to the improved $43 \%, 79 \%$, and $>95 \%$ growth reduction $(p<0.05)$, respectively (Fig. 2$)$. Thus, the IFN- $\mathrm{a}_{2 b} / \mathrm{GSP}$ combinations appear to induce the additive antiproliferative effects on T24 cells.

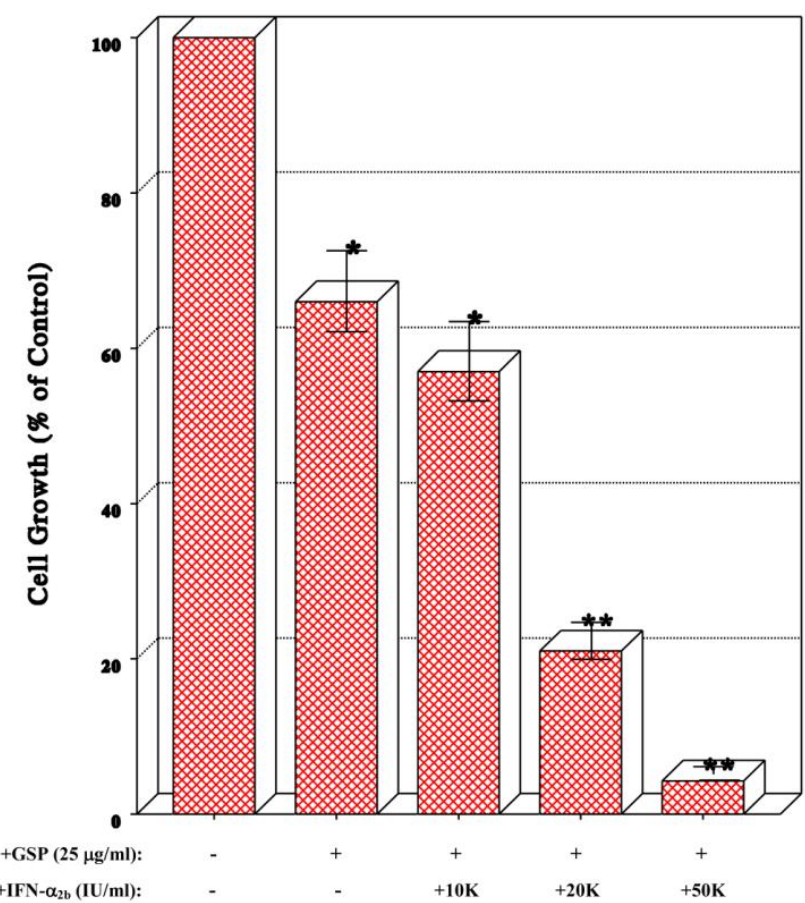

Fig. 2. Effects of combination of IFN- $\alpha_{2 b}$ and GSP on cell growth. Cells were treated with combinations of GSP $(25 \mu \mathrm{g} / \mathrm{ml})$ and IOK, $20 \mathrm{~K}$, or $50 \mathrm{~K} \mathrm{IU} / \mathrm{ml}$ of IFN- $\alpha_{2 b}$ for $72 \mathrm{~h}$, and cell growth was assessed by the $\%$ of viable cell numbers relative to that in control ( $100 \%)$. The data are mean \pm SD from three separate experiments $(* p<0.05 ; * * p<0.03)$.

\section{Effects of IFN- $\alpha_{2 b}$ and GSP on cell cycle}

To explore the mechanism of such additive effects of the IFN- $\mathrm{a}_{2 b} / \mathrm{GSP}$ combinations, cell cycle analysis was performed using the specific concentrations of IFN- $\mathrm{a}_{2 \mathrm{~b}}(20 \mathrm{KIU} / \mathrm{ml})$ and GSP $(25 \mu \mathrm{g} / \mathrm{ml})$, which seemed to be rather suitable for this study. After T24 cells were treated with IFN- $\mathrm{a}_{2 b}(20 \mathrm{~K} \mathrm{IU} / \mathrm{ml})$, GSP $(25$ 
$\mu \mathrm{g} / \mathrm{ml}$ ), or their combination for $72 \mathrm{~h}$, the results of cell cycle analysis were then summarized in Table 1 . Compare to cell numbers of the $G_{1}$ and $S$ phases in controls, significant changes in those numbers $(p<0.05)$ were seen with IFN- $\mathrm{a}_{2 b}$ treatment, while GSP alone showed only the marginal effects. In contrast, the IFN- $a_{2 b} /$ GSP combination induced a $58 \%$ increase and $64 \%$ decrease in $G_{1}$ and $S$ phase cell numbers $(p<0.05)$, respectively. This cell accumulation in the $\mathrm{G}_{1}$ phase is known as a $G_{1}$ cell cycle arrest (18). Thus, the IFN- $\mathrm{a}_{2 b}$ /GSP combination may primarily target the $\mathrm{G}_{1}-\mathrm{S}$ phase transition in the cell cycle, subsequently leading to the growth cessation.

Table I Effects of IFN- $\alpha_{2 b}$ and GSP on Cell Cycle Phase Distributions.

\begin{tabular}{lccc}
\hline Conditions & \multicolumn{3}{c}{$\%$ of Cells in Cell Cycle Phases } \\
\cline { 2 - 4 } & $\mathrm{G}_{1}$ & $\mathrm{~S}$ & $\mathrm{G}_{2} / \mathrm{M}$ \\
\hline Control & $49.3 \pm 4.7$ & $38.1 \pm 2.8$ & $12.6 \pm 1.4$ \\
$\begin{array}{l}\text { + IFN- } \alpha_{2 \mathrm{~b}}(20 \mathrm{~K} \\
\mathrm{IU} / \mathrm{ml})\end{array}$ & $61.7 \pm 4.6^{*}$ & $26.7 \pm 3.1^{*}$ & $11.6 \pm 1.1$ \\
$+\mathrm{GSP}(25 \mu \mathrm{g} / \mathrm{ml})$ & $56.7 \pm 5.0$ & $33.2 \pm 2.9$ & $10.1 \pm 1.6$ \\
$+\mathrm{IFN}-\alpha_{2 \mathrm{~b}}$ & $77.9 \pm 4.3^{*}$ & $13.6 \pm 1.4^{*}$ & $8.5 \pm 0.9$ \\
$(20 \mathrm{~K}) / \mathrm{GSP}(25)$ & & & \\
\hline
\end{tabular}

All data are mean \pm SD from three separate experiments.

${ }^{*} p<0.05$ (compared to those in Control).

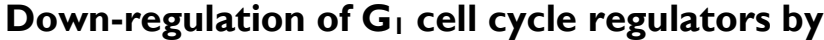 IFN- $\alpha_{2 b} /$ GSP combination}

To confirm such an IFN- $\alpha_{2 b} /$ GSP-induced $G_{1}$ cell cycle arrest, we also examined its effects on the specific cell cycle regulators for the $\mathrm{G}_{1}-\mathrm{S}$ phase transition (18). After cells were treated with or without the IFN- $\alpha_{2 b}(20 \mathrm{~K} \mathrm{IU} / \mathrm{ml}) / \mathrm{GSP}(25 \mu \mathrm{g} / \mathrm{ml})$ combination for $72 \mathrm{~h}$, the expressions of CDK2, CDK4, cyclin $\mathrm{D}_{1}$, cyclin $\mathrm{E}$, and p27/Kip1 were analyzed on Western blots. Such analysis revealed that the expressions of CDK2, CDK4 and cyclin E were drastically reduced by $\sim 80 \%$ with the IFN- $\mathrm{a}_{2 \mathrm{~b}} / \mathrm{GSP}$ treatment (compared to those in controls), although no change in cyclin $\mathrm{D}_{1}$ was observed (Fig. 3). In contrast, p27/Kip1 protein, a CDK2 inhibitor, was significantly ( 2.7 fold) up-regulated in IFN- $\mathrm{a}_{2 \mathrm{~b}} / \mathrm{GSP}$-treated cells (Fig. 3). Thus, altered expressions of these regulators would provide the further evidence for a blockage of $\mathrm{G}_{1}-\mathrm{S}$ phase transition, confirming that the IFN-a $\mathrm{a}_{2 \mathrm{~b}} / \mathrm{GSP}$-induced growth inhibition is indeed mediated through a $\mathrm{G}_{1}$ cell cycle arrest.

\section{Control IFN/GSP}

CDK2

CDK4

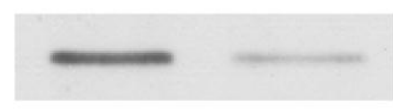

Cyclin $D_{1}$

Cyclin E

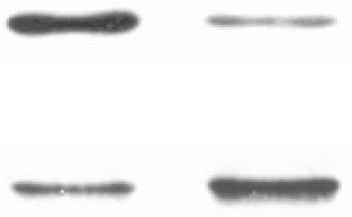

Fig. 3. Western blot analysis on cell cycle regulators. After cells were treated with or without the combination of IFN- $\alpha_{2 b}(20 \mathrm{~K}$ $\mathrm{IU} / \mathrm{ml})$ and GSP $(25 \mu \mathrm{g} / \mathrm{ml})$ for $72 \mathrm{~h}$, the expressions of several cell cycle regulators were analyzed on Western blots. Autoradiographs of CDK2, CDK4, cyclin DI, cyclin E, and p27/Kipl in control and IFN- $\alpha_{2 b} / G S P$-treated cells are shown for comparison.

\section{Effects of IFN- $\alpha_{2 b} /$ GSP combination on prolif- eration of other cancer cells}

Now, one may raise the question if the IFN- $\mathrm{a}_{2 \mathrm{~b}} / \mathrm{GSP}$ combination would also demonstrate its enhanced antiproliferative effect on other bladder cancer cells or different cancer cell types. This was tested using another bladder cancer 5637 cells, prostate cancer PC-3 cells, and renal cancer ACHN cells, which had been treated with IFN- $\mathrm{a}_{2 b}(20 \mathrm{~K} \mathrm{IU} / \mathrm{ml})$, GSP $(25 \mu \mathrm{g} / \mathrm{ml})$, or their combination for $72 \mathrm{~h}$. Figure 4 shows the effects of these agents on proliferation of three cancer cell lines. Overall, all cancer cells treated with various agents exhibited altered growth patterns, which were significantly different from their respective control cells $(p<0.05)$. IFN- $\mathrm{a}_{2 \mathrm{~b}}$ alone was capable of inducing a $\sim 50 \%$ growth inhibition in both PC-3 and ACHN cells but a $~ 30 \%$ inhibition in 5637 cells. GSP alone caused a lesser but $22-37 \%$ growth reduction in all these cells. Nevertheless, the IFN- $\mathrm{a}_{2 \mathrm{~b}} / \mathrm{GSP}$ combination resulted in an enhanced $70 \%, 71 \%$, and $68 \%$ growth inhibition in 5637 , PC-3, and ACHN cells, respectively. Thus, these results suggest that the IFN- $\mathrm{a}_{2 b} / \mathrm{GSP}$ combination may commonly demonstrate its potentiated antiprolifera- 
tive effect on not only T24 cells but also a variety of human cancer cells.

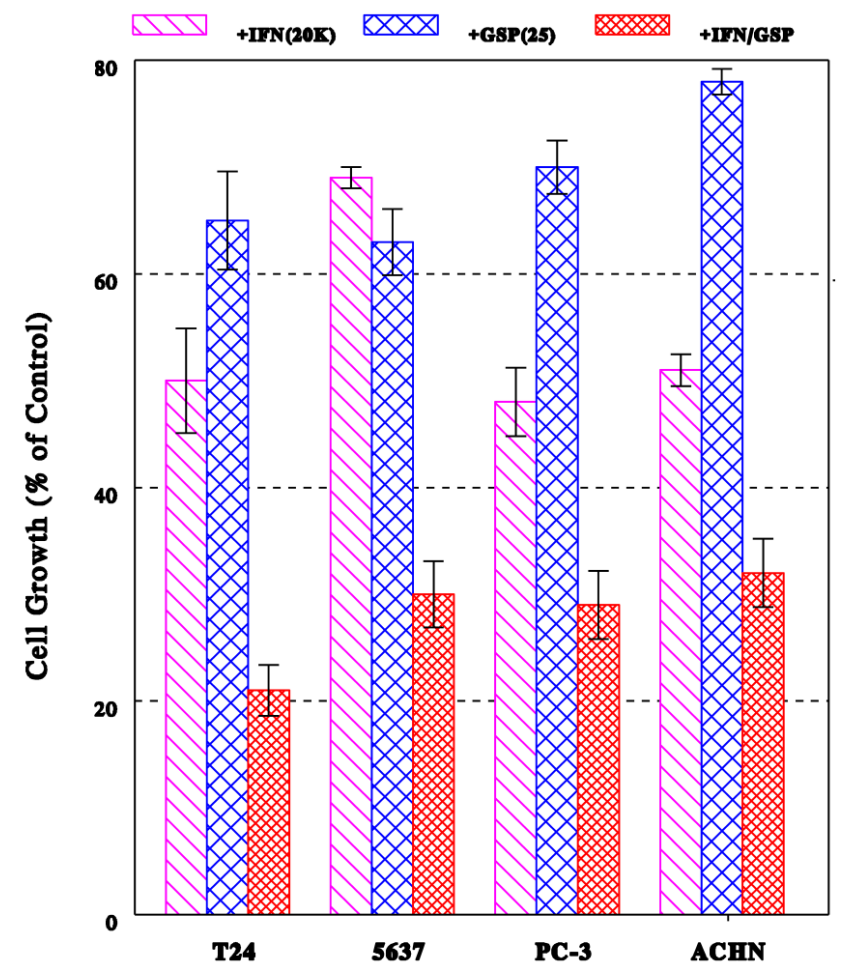

Fig. 4. Growth inhibitory effect of IFN- $\alpha_{2 b} / G S P$ combination on various cancer cells. Bladder cancer 5637, prostate cancer PC-3, and renal cancer $A C H N$ cells were treated with IFN- $\alpha_{2 b}(20 \mathrm{~K}$ $\mathrm{IU} / \mathrm{ml})$, GSP $(25 \mu \mathrm{g} / \mathrm{ml})$, or their combination for $72 \mathrm{~h}$, and cell growth was assessed by the \% of viable cell number (in each condition) relative to that in respective control cells. The growth profile of T24 cells is also shown for comparison. All data are mean \pm SD from three separate experiments, showing statistically significant differences $(p<0.05)$ compared to respective controls (100\%).

\section{Discussion}

Although IFN-a has been often used as immunotherapy for bladder cancer because of its relatively low toxicity (compared to BCG), its less efficacy has been also inquired for a significant improvement. Additionally, IFN-a therapy has several drawbacks, such as high cost and repeated administration. A standard intravesical IFN-a instillation is often carried out with 50-100 million IU of IFN-a (19), but whether this high dosage would be sufficient to induce optimal immunity is uncertain because of its short retention time inside the bladder (19). Accordingly, to improve the efficacy of such IFN-a monotherapy, clinical trials of combination therapy using IFN-a and BCG (11) have been conducted on patients with bladder cancer. Despite some encouraging outcomes, further studies are yet required for establishing the more potent, safer, and cost-effective treatment modalities.

This interesting issue prompted us to explore an alternative approach using grape seed proanthocyanidin (GSP) in combination with IFN- $\mathrm{a}_{2 \mathrm{~b}}$, because GSP has been shown to be a natural, non-toxic antioxidant with anticancer effect $(15,16)$. Our study showed that IFN- $a_{2 b}$ or GSP was capable of individually inducing a significant growth reduction in T24 cells. Interestingly, GSP also exhibited the cytotoxic effect (inducing cell death) at its higher concentrations $(\geq 50 \mu \mathrm{g} / \mathrm{ml})$. When combinations of IFN- $\alpha_{2 b}$ and GSP were tested to further improve the overall efficacy, all combinations resulted in the additively enhanced antiproliferative effect, implying that both IFN- $\mathrm{a}_{2 b}$ and GSP may share the common growth regulatory pathway. In addition, this IFN- $\mathrm{a}_{2 \mathrm{~b}} / \mathrm{GSP}$-enhanced growth inhibition in T24 cells was also demonstrated in another bladder cancer (5637), prostate cancer (PC-3), and renal cancer (ACHN) cells (Fig. 4), suggesting its prevalent potency over bladder cancer as well as various cancer cells.

Our next aim was to probe the antiproliferative mechanism of IFN- $\mathrm{a}_{2 b}$ /GSP combination, focusing on the cell cycle regulation. Such study revealed that the IFN-a $a_{2 b} / G S P-i n d u c e d$ growth inhibition was associated with a $64 \%$ reduction in the S-phase cell population, due to a blockage of the cells entering from the $\mathrm{G}_{1}$ to the subsequent $S$ phase (i.e. a $\mathrm{G}_{1}$ cell cycle arrest). This finding was also verified by analyzing $\mathrm{G}_{1}$-specific cell cycle regulators: expressions of CDK2, CDK4, and cyclin E were drastically $(\sim 80 \%)$ down-regulated while p27/Kip1 was greatly $(\sim 2.7$ fold) up-regulated in IFN-a $\mathrm{a}_{2 b} / \mathrm{GSP}$-treated cells. Specific modulations of these regulators are indicative of a $G_{1}$ cell cycle arrest, which is the crucial cellular event leading ultimately to a growth cessation. Yet, it is also important to examine the IFN-mediated signaling pathways to further define the mechanism of IFN- $\mathrm{a}_{2 \mathrm{~b}}$ /GSP-induced growth inhibition, since activation of specific IFN-inducible genes by signal transduction (20) is well known to dictate biological actions of IFNs (including IFN- $a_{2 b}$ ). Such study is currently underway in our laboratory.

It would be worthwhile mentioning the possible clinical relevance of IFN- $\mathrm{a}_{2 b} /$ GSP-enhanced antiproliferative effect. As a high-dose instillation of IFN-a leads to its high cost (19), it would be more practical if such a high dosage could be somehow reduced without losing, or rather, with improving its efficacy. Our study then showed that the relatively low concentrations of IFN- $a_{2 b}$ (compared to its monotherapy) were required to be highly effective when combined with GSP. This suggests that the combination of 
IFN- $\alpha_{2 b}$ and GSP may not only help enhance IFN- $\alpha_{2 b}$ activity but also help cut its cost down. However, it is yet required to address how the effective concentrations (e.g., $20 \mathrm{~K}$ or $50 \mathrm{~K} \mathrm{IU} / \mathrm{ml}$ ) of IFN- $\mathrm{a}_{2 b}$ and GSP in this in vitro study would be extrapolated to animals or actual patients. Nevertheless, several studies have already reported antitumor activity of GSP in vivo. For example, GSP was found to inhibit prostate tumor growth and angiogenesis (21) as well as breast cancer metastasis in mice (22) or enhance cytotoxic effect of doxorubicin in mice bearing Sarcorma 180 and Hepatoma 22 (23). No palpable side effects of GSP have been yet reported in these animal studies, and the $\mathrm{LD}_{50}$ of GSP in the rats has been estimated to be $>5,000$ $\mathrm{mg} / \mathrm{kg}$ body weight (24), verifying its low toxicity. Moreover, patients with chronic pancreatitis demonstrated the symptomatic improvements, such as the reduction in both pain index and incidence of vomiting (25), with a daily dose of $200-300 \mathrm{mg}$ of GSP. This also implies that GSP may have few side effects and is safe to be used in clinical practice.

In conclusion, IFN- $a_{2 b}$ and GSP can individually demonstrate antiproliferative effect on bladder cancer T24 cells. When they were combined, such inhibitory activity would be additively enhanced, resulting in a nearly complete growth cessation. In addition, this additive potentiation can be seen in other cancer cell types as well. The underlying mechanism of IFN- $\mathrm{a}_{2 b}$ /GSP-enhanced growth inhibition appears to be more likely attributed to a $\mathrm{G}_{1}$ cell cycle arrest. Therefore, specific IFN- $\mathrm{a}_{2 b} / \mathrm{GSP}$ combination may provide alternative, adjuvant intravesical therapy for superficial bladder cancer.

\section{Conflict of Interest}

The authors have declared that no conflict of interest exists.

\section{References}

1. Pow-Sang JM, Seigne JD. Contemporary management of superficial bladder cancer. Cancer Control. 2000; 7: 335-9.

2. Witjes JA, Mulders PF, Debruyne FM. Intravesical therapy in superficial bladder cancer. Urology. 1994; 43: 2-5.

3. Alexandroff AB, Jackson AM, O'Donnell MA, James K. BCG immunotherapy of bladder cancer: 20 years on. Lancet. 1999; 353: 1689-94.

4. Lamm DL, Blumenstein BA, Crawford ED, et al. A randomized trial of intravesical doxorubicin and immunotherapy with bacillus Calmette-Guerin for transitional-cell carcinoma of the bladder. N Engl J Med. 1991; 325: 1205-9.

5. Herr HW, Schwalb DM, Zhang ZF, et al. Intravesical bacillus Calmette-Guerin therapy prevents tumor progression and death from superficial bladder cancer: ten-year follow-up of a prospective randomized trial. J Clin Oncol. 1995; 13: 1404-8.

6. Amling CL. Diagnosis and management of superficial bladder cancer. Curr Probl Cancer. 2001; 25: 219-78.
7. Harris DT, Matyas GR, Gomella LG, et al. Immunologic approaches to the treatment of prostate cancer. Semin Oncol. 2000; 26: 439-47.

8. Glashan RW. A randomized controlled study of intravesical alpha-2b-interferon in carcinoma in situ of the bladder. J Urol. 1990; 144: 658-61.

9. Bukowski RM. Cytokine therapy for metastatic renal cell carcinoma. Semin Urol Oncol. 2001; 19: 148-54.

10. Belldegrun AS, Franklin JR, O'Donnell MA, et al. Superficial bladder cancer: the role of interferon-alpha. J Urol. 1998; 159: 1793-1801.

11. Stricker P, Pryor K, Nicholson T, et al. Bacillus Calmette-Guerin plus intravesical interferon alpha- $2 \mathrm{~b}$ in patients with superficial bladder cancer. Urology. 1996; 48: 957-61.

12. Gan YH, Zhang Y, Khoo HE, Esuvaranathan K. Antitumor immunity of Bacillus Calmette-Guerin and interferon alpha in murine bladder cancer. Eur J Cancer. 1999; 35: 1123-9.

13. Bagchi D, Garg A, Krohn RL, Bagchi M, Tran MX, Stohs SJ. Oxygen free radical scavenging abilities of vitamins $C$ and $E$, and a grape seed proanthocyanidin extract in vitro. Res Commun Mol Pathol Pharmacol. 1997; 95: 179-89.

14. Bagchi D, Kuszynski CA, Balmoori J, Bagchi M, Stohs SJ. Hydrogen peroxide-induced modulation of intracellular oxidized states in cultured macrophage J774A.1 and neuroactive PC-12 cells, and protection by a novel grape seed proanthocyanidin extract. Phytother Res. 1998; 12: 568-71.

15. Joshi SS, Kuszynski CA, Bagchi M, Bagchi D. Chemopreventive effects of grape seed proanthocyanidin extract on Chang liver cells. Toxicology. 2000; 155: 83-90.

16. Ye X, Krohn RL, Liu W, et al. The cytotoxic effects of a novel IH636 grape seed proanthocyanidin extract on cultured human cancer cells. Mol Cell Biochem. 1999; 196: 99-108.

17. Mordente JA, Konno S, Chen Y, Wu JM, Tazaki H, Mallouh C. The effects of brefeldin A (BFA) on cell cycle progression involving the modulation of the retinoblastoma protein $(\mathrm{pRB})$ in PC-3 prostate cancer cells. J Urol. 1998; 159: 275-9.

18. Sherr CJ. The Pezcoller lecture: cancer cell cycles revised. Cancer Res. 2000; 60: 3689-95.

19. Luo $Y$, Chen X, Han R, O'Donnell MA. Recombinant bacille Calmette-Guerin (BCG) expressing human interferon-alpha 2B demonstrates enhanced immunogenicity. Clin Exp Immunol. 2001; 123: 264-70.

20. Bandyopadhyay SK, Rackley RR, Matin SF, Sadhukhan PC. Interferon- $\alpha$ response and signal transduction pathway in transitional carcinoma cell lines. Adv Exp Med Biol. 2003; 539 (Pt A): 15-32.

21. Singh RP, Tyagi AK, Dhanalakshmi S, Agarwal R, Agarwal C. Grape seed extract inhibits advanced human prostate tumor growth and angiogenesis and upregulates insulin-like growth factor binding protein-3. Int J Cancer. 2004; 108: 733-40.

22. Mantena SK, Baliga MA, Katiyar SK. Grape seed proanthocyanidins induce apoptosis and inhibit metastasis of highly metastatic breast carcinoma cells. Carcinogenesis. 2006; 27: 1682-91.

23. Zhang XY, Bai DC, Wu YJ, Li WG, Liu NF. Proanthocyanidin from grape seeds enhances anti-tumor effect of doxorubicin both in vitro and in vivo. Pharmazie. 2005; 60: 533-8.

24. Bagchi D, Bagchi M, Stohs SJ, et al. Free radicals and grape seed proanthocyanidin extract: importance in human health and disease prevention. Toxicology. 2000; 148: 187-97.

25. Banerjee B, Bagchi D. Beneficial effects of a novel IH636 grape seed proanthocyanidin extract in the treatment of chronic pancreatitis. Digestion. 2001; 63: 203-6. 